\title{
Erratum to: A commentary on the 2015 Canadian Clinical Practice Guidelines in glutamine supplementation to parenteral nutrition
}

Alberto Leguina-Ruzzi

The author would like to issue an erratum for this article [1], and would like to declare the following competing interests which were inadvertently missed in the original publication.

Competing interests

I declare that I worked as an external freelance scientific consultant for Fresenius Kabi in Chile. My work has been limited to bibliographical analysis in the metabolic field non related with clinical practice. I have not endorsed products of Fresenius Kabi company, particularly Dipeptiven.

Received: 19 January 2016 Accepted: 19 January 2016

Published: 25 January 2016

\section{Reference}

1. Leguina-Ruzzi A. A commentary on the 2015 Canadian Clinical Practice Guidelines in glutamine supplementation to parenteral nutrition. Critical Care. 2016;20:7.

Correspondence: aaleguin@uc.cl

Hematology and Oncology, Department of Medicine, Pontificia Universidad Católica de Chile, Santiago, Chile, Portugal 61, Second Floor, Santiago 8330034, Chile
Submit your next manuscript to BioMed Central and we will help you at every step:

- We accept pre-submission inquiries

- Our selector tool helps you to find the most relevant journal

- We provide round the clock customer support

- Convenient online submission

- Thorough peer review

- Inclusion in PubMed and all major indexing services

- Maximum visibility for your research

Submit your manuscript at www.biomedcentral.com/submit
() Biomed Central 